\title{
THE IMPACT OF DIGITALIZATION AND ERP SYSTEMS ON THE SUSTAINABLE DEVELOPMENT OF THE ORGANIZATION
}

\author{
Laura-Eugenia-Lavinia Barna*
}

Bucharest University of Economic Studies, Accounting, Romania, barnalaura15@stud.ase.ro

\begin{abstract}
There is a very strong relationship between the concept of digitalization and the concept of sustainable development, because the more automated the processes within the organization, the lower inefficient consumption of resources and the negative impact on the environment are. Given the characteristics of accounting information systems, organizations have come to the conclusion that ERP systems are the most appropriate system to ensure the digitization of processes and sustainable development of the organization. Under such perspectives, the paper employs an empirical direction comprising a questionnaire, analyzed with the aid of Microsoft Excel where the sensitivity model was developed. The results show that ERP systems have a favorable impact on the sustainable development of the organization, given the large volume of data that can be processed with these information systems and through which resource consumption is significantly lower. Thus, based on the processed information, managers make very important decisions for the continuity of the organization's activity.
\end{abstract}

Keywords:

Sustainability, decision, ERP systems, digitalization, impact

JEL Classification: M10, M15, M41

DOI: $10.24818 / \mathrm{CTS} / 3 / 2021 / 2.04$

\section{Introduction}

The development of the economic environment was possible due to the evolution of technology and the need for organizations to automate most of their daily activities. The purpose of this paper is to observe whether the digitalization and use of ERP systems have an impact on the sustainable development of the organization.

According to Rajal and Baral (2015, p. 105), organizations should take into account the evolution of technology and "to invest in complex IT systems, such as integrated ERP systems" that incorporate functions specific to different departments within the organization. By investing in this equipment, organizations have the opportunity to increase productivity and streamline their daily activities, leading to "reducing inefficient consumption of resources" and thus the ability to develop sustainably in the short, medium and long term (Hasan et al., 2019; Kandananond, 2014).

According to a study conducted by Vodafone (2020, cited by Ziarul Financiar, 2021), several organizations have encountered various difficulties in the digitization process such as:

- " $73 \%$ of the organizations encountered difficulties in implementing the technologies or in integrating the existing technologies with the business processes"

- " $51 \%$ had problems identifying the right technology or supplier"

- " $38 \%$ needed support through training"

Following the integration of business processes, all information will be stored in the database of ERP systems giving users in that organization the opportunity to access the information stored in the database thus reducing the amount of printed paper thus providing the opportunity to sustainably grow that organization.

\footnotetext{
* contact author
} 
The article is structured in 4 sections: reviewing the literature, presenting the research method used, the results obtained based on the sensitivity model created and summarizing the main conclusions.

\section{Literature review}

ERP systems have an important role in managing and carrying out the organization's activity, being thus defined as "a unique platform, useful for monitoring, control and integrated management of all activities, processes and operations carried out by a company" (Transart, 2021). The use of ERP systems determines the significant improvement of the flow of information between departments, so that the activities within the organization can be carried out much more efficiently.

Weinrich and Ahmad (2009, cited by Rajal and Baral, 2015) identified the main modules of an ERP system useful in improving business processes: supply, production, sales, finance, accounting, human resources and specific modules depending on the specifics of the activity.

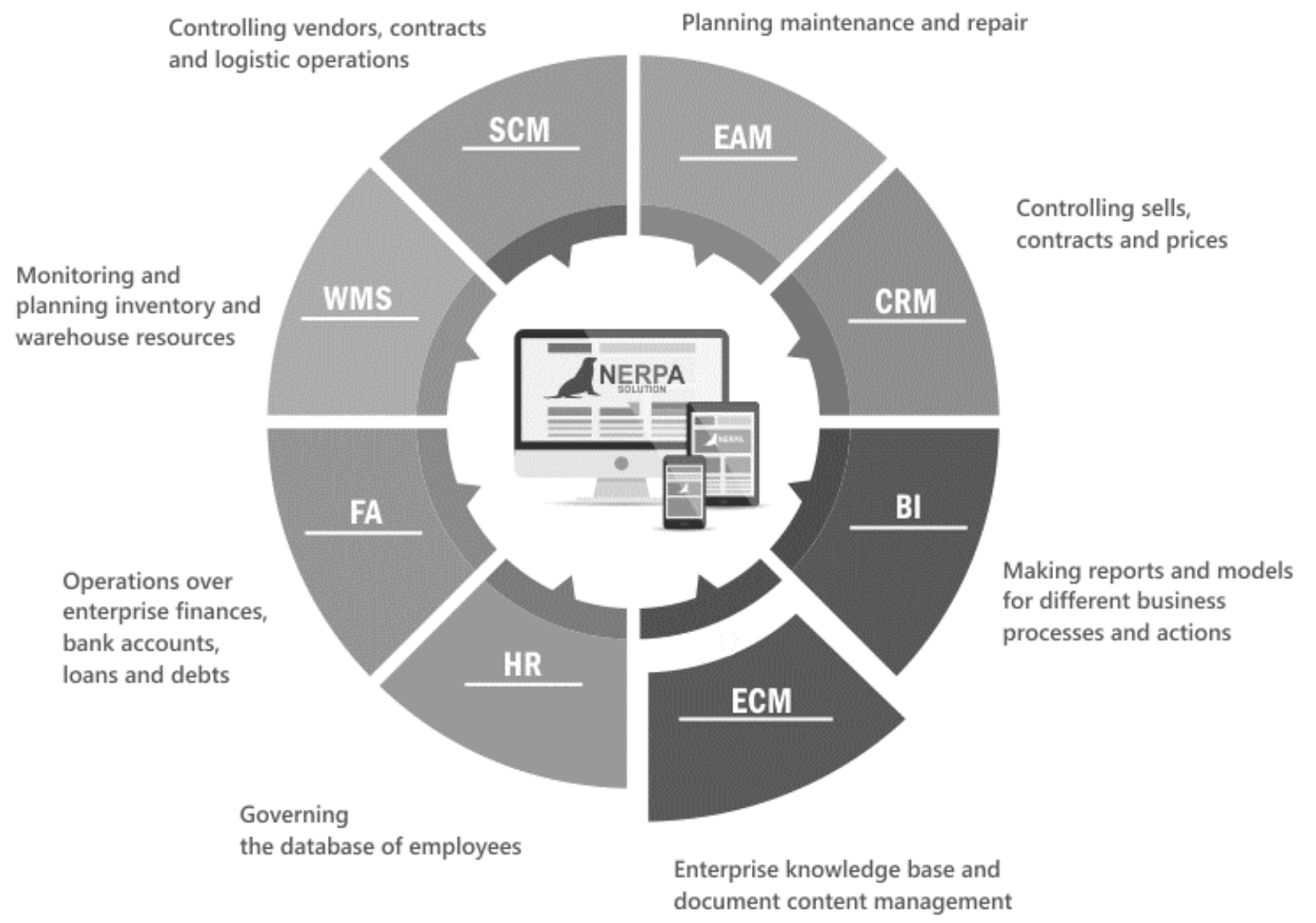

Fig. no. 1: ERP system modules

Source: Novosoft LLC

Sustainable development is often considered by organizations as a starting point for establishing the organization's strategy (Danciu, 2013). The reasons why a company decides to adopt a sustainable development strategy are presented in figure no. 2 . 


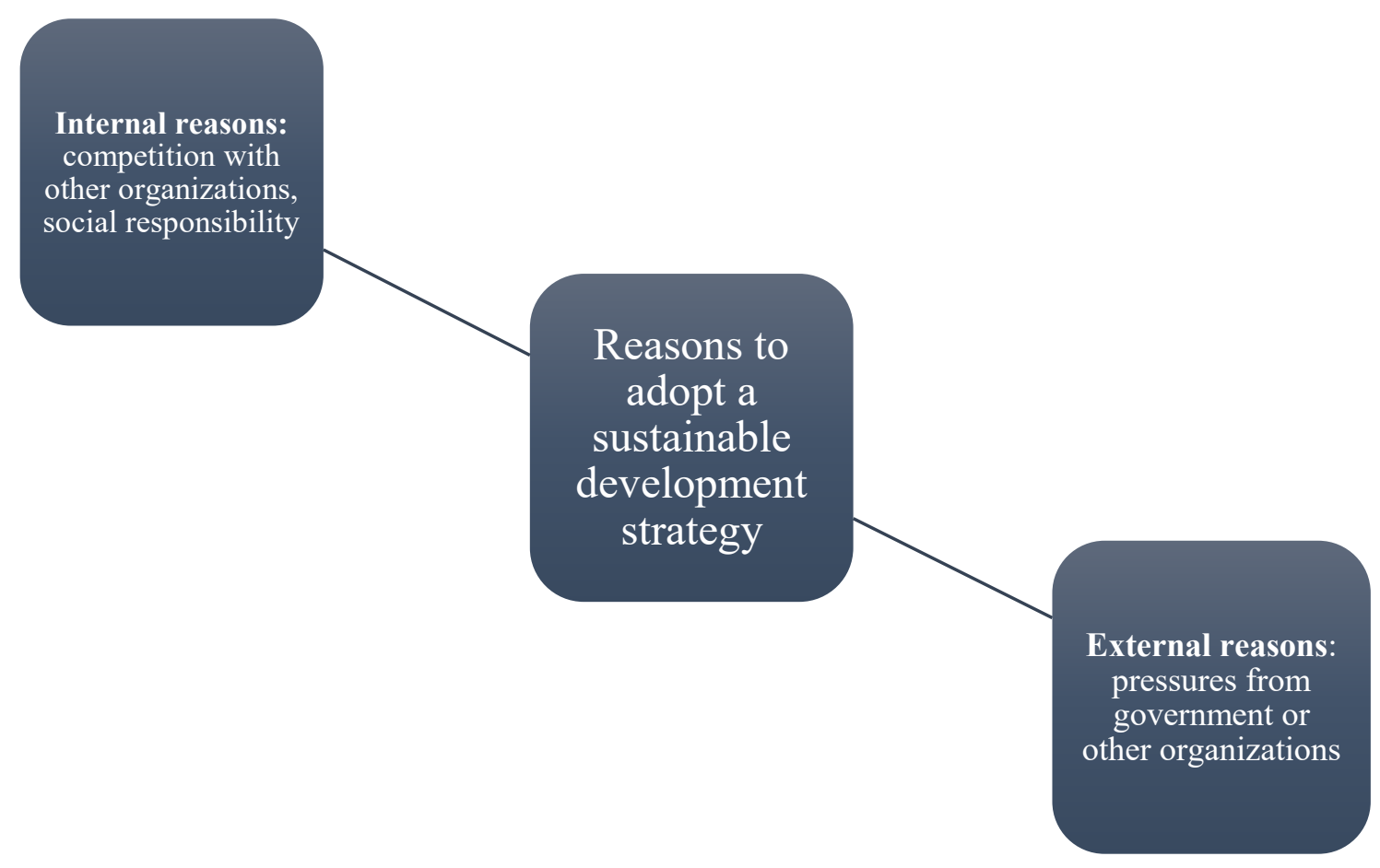

Fig. no. 2: Reasons to adopt a sustainable development strategy

Source: Danciu, 2013

Mathews (2015) believes that organizations can grow sustainably if: they reduce inefficient consumption and use complementary resources. Karagulle (2012, p. 457) offered the definition of a green business as a "business practice valued as green such as "the use of strict protections against emissions, the supply of ecological resources and the efficient and economical use of resources" must use devices (IT equipment) that consume as little electricity as possible to ensure a decrease in electricity costs for the company and to grow sustainably. The main role of sustainable development is to ensure value creation over as long a period of time as possible, and everything is possible only if clear and complete information is provided by integrated ERP information systems (Knut, 2016).

Mirghafoori et al. (2017, p. 2) give an opinion that organizations must show a "responsible behavior towards society and the environment". Many specialized sites such as Gradient Consulting (2020), Alfa Software.ro (2019) and Transart (2021) are of the opinion that ERP systems offer users the opportunity to have access to clear, complete and correct processed information, having a primary role in the decision-making process.

Watson et al. (2010, cited by Bradford et al., 2012, p. 31) states that integrated ERP systems can provide "a multilateral view of the organization" because all processed information is stored in a common database.

\section{Methodology}

The research method used in this paper was quantitative based on a survey. The questionnaire was launched on the isondaje.ro platform, between November 1, 2020 - November 30, 2020, and the sample of respondents consisted of students from the Bucharest University of Economic Studies and employees in the economic field. The questions in the questionnaire were single-answer questions, open-ended questions or questions with evaluation scales (Likert scale in 5 steps, where at value 1 the respondents disagreed, and value 5 represented the respondents' agreement on the statements).

Based on the data collected, I created a sensitivity model that would answer the following research questions:

Q1: How do users perceive the volume of data processed with ERP systems?

Q2: What is the users' perception regarding the modernization of ERP systems? 
Q3: Following the implementation of the ERP system, has an improvement in labor productivity been observed?

Q4: Do training programs support the organization to develop sustainably?

The sensitivity model includes the following elements presented in table no. 1:

Table no. 1: Sensitivity model

\begin{tabular}{|l|l|c|}
\hline No. & \multicolumn{1}{|c|}{ Components } & Code \\
\hline 1 & The volume of data processed with ERP systems & S-VOLUM \\
\hline 2 & The degree of modernization of ERP systems & S-MODERN \\
\hline 3 & Improving labor productivity & S-LABOR \\
\hline 4 & Support provided by training programs for sustainable development & S-SUPORT \\
\hline
\end{tabular}

Source: own creation

In the next section I will present the results obtained based on the sensitivity model achieved.

\section{Results}

The sample of respondents is presented in figure no. 3 and consists of students and employees in the economic field:

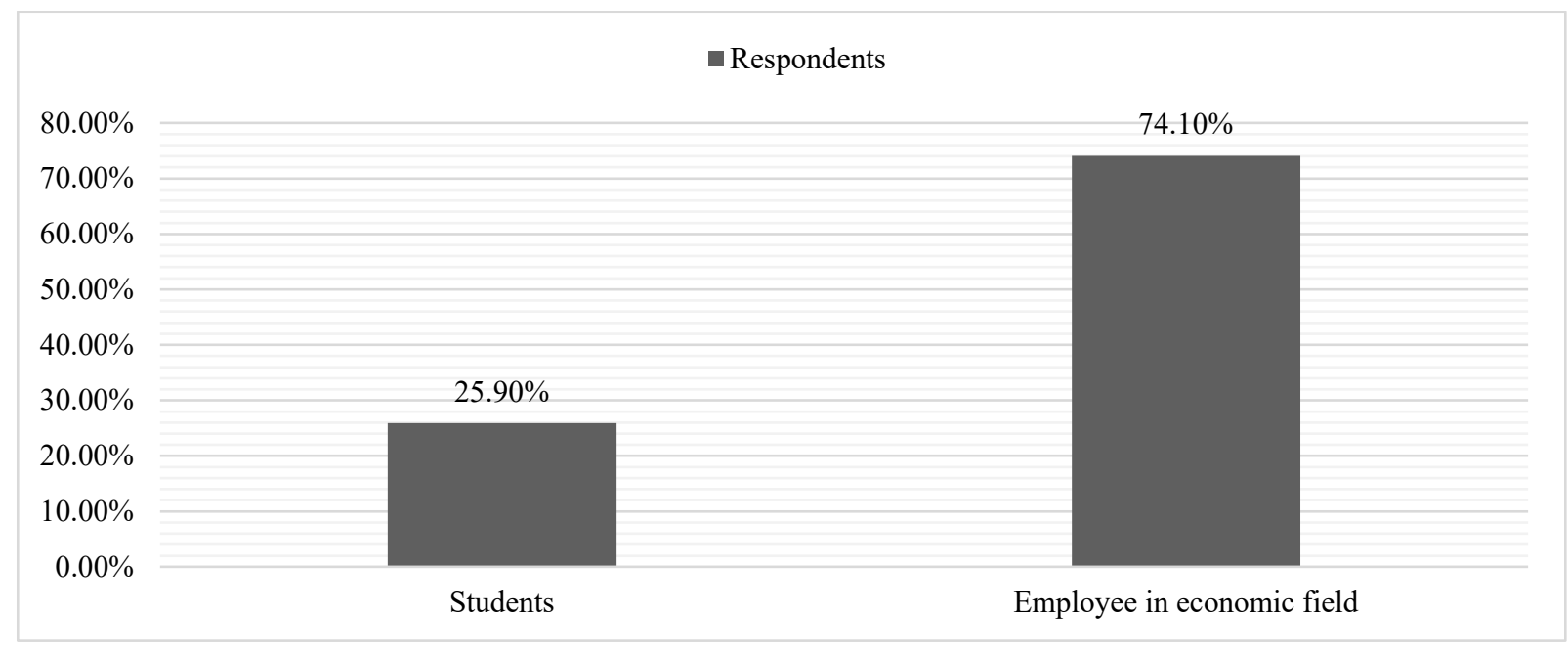

Fig. no. 3: The sample of respondents

Source: own creation

Most respondents are female, because most students enrolled in Romania are female according to a study conducted by ANS (2020). Thus, the predominant labor force in the economic field is female (table no. 2).

Table no. 2: Distribution of respondents by gender and area of residence

\begin{tabular}{|l|c|c|}
\hline \multirow{2}{*}{ Area of residence } & \multicolumn{2}{|c|}{ Gender } \\
\cline { 2 - 3 } & Female & Male \\
\hline Urban area & 77 & 11 \\
\hline Rural area & 15 & 9 \\
\hline Total & $\mathbf{9 2}$ & $\mathbf{2 0}$ \\
\hline
\end{tabular}

Source: own creation

In the research I used the Likert scale with 5 values (1 representing very little, 5 representing very much), through which the respondents expressed their agreement or disagreement with certain statements. In the next tables, I will present the results obtain with the sensitivity model, grouped by each category of respondents. 
Table no. 3: Answers from students distributed according to their gender

\begin{tabular}{|l|c|c|}
\hline \multirow{2}{*}{ Sensitivity model variables } & \multicolumn{2}{|c|}{ Gender } \\
\cline { 2 - 3 } & Female & Male \\
\hline S-VOLUM & 3,05 & 3,15 \\
\hline S-MODERN & 4,41 & 4,3 \\
\hline S-LABOR & 4,21 & 4,25 \\
\hline S-SUPORT & 3,49 & 3,2 \\
\hline
\end{tabular}

Source: own creation

According to the data in table no. 3, respondents believe that the sustainable development of an organization can be further ensured through the modernization of information technologies used by that organization (4,41 / 5 for female respondents and 4,3 / 5 for male respondents), which implicitly leads to improved labor productivity $(4,21 / 5$ for female respondents and 4,25 / 5 for male respondents) because the flow of information is much clearer and information is complete and correct, given that the 2 variables of the sensitivity model obtained the highest score for the answers received from the students according to their gender.

Table no. 4: Answers from employees distributed according to their seniority in work in the economic field

\begin{tabular}{|l|c|c|c|c|}
\hline \multirow{2}{*}{$\begin{array}{c}\text { Seniority in work } \\
\text { in the economic } \\
\text { field }\end{array}$} & \multicolumn{4}{|c|}{ Sensitivity model variables } \\
\cline { 2 - 5 } & S-VOLUM & S-MODERN & S-LABOR & S-SUPORT \\
\hline $\begin{array}{l}\text { Less than } \\
\text { months }\end{array}$ & 2,89 & 4,33 & 4,13 & 3,57 \\
\hline 6 month - 1 year & 3,15 & 4,23 & 4,19 & 3,27 \\
\hline 1 year - 5 years & 3,42 & 4,58 & 4,42 & 3,38 \\
\hline 5 years - 10 years & 2,67 & 4,67 & 3,33 & 2,17 \\
\hline $\begin{array}{l}\text { More than 10 } \\
\text { years }\end{array}$ & 3 & 5 & 5 & 4,17 \\
\hline
\end{tabular}

Source: own creation

According to table no. 4 highest scores were obtained by modernizing information systems and improving productivity regardless of the seniority of respondents in work. The maximum score of 5 was obtained in the case of respondents who are a seniority more than 10 years, because they have more experience in the economic field and throughout their career they have encountered different situations. Respondents also stated that the new ERP systems provide more clearly processed information and allow the creation of monthly or annual reports more easily. At the same time, the respondents believe that the integrated ERP systems have the role of automating an increasing number of activities due to the evolution of digitalization and information systems.

Another role of ERP systems is to improve profitability, reduce system maintenance costs and secure data much better.

Also, an important role in both the sustainable development process and in the professional development is played by the training programs offered by the organization, because they have the role of helping the employees to integrate more easily in the organization, making them much more productive.

The professional development of employees allows them to "invest more time in its professional training" (Stefanidis, 2017), so that they can cope with the work tasks within the organization. 
According to figure no. 4, sustainable development can be ensured by implementing high-performance integrated ERP information systems, this being agreed by the respondents because they consider that the new ERP systems are much more efficient and allow the exact use of resources.

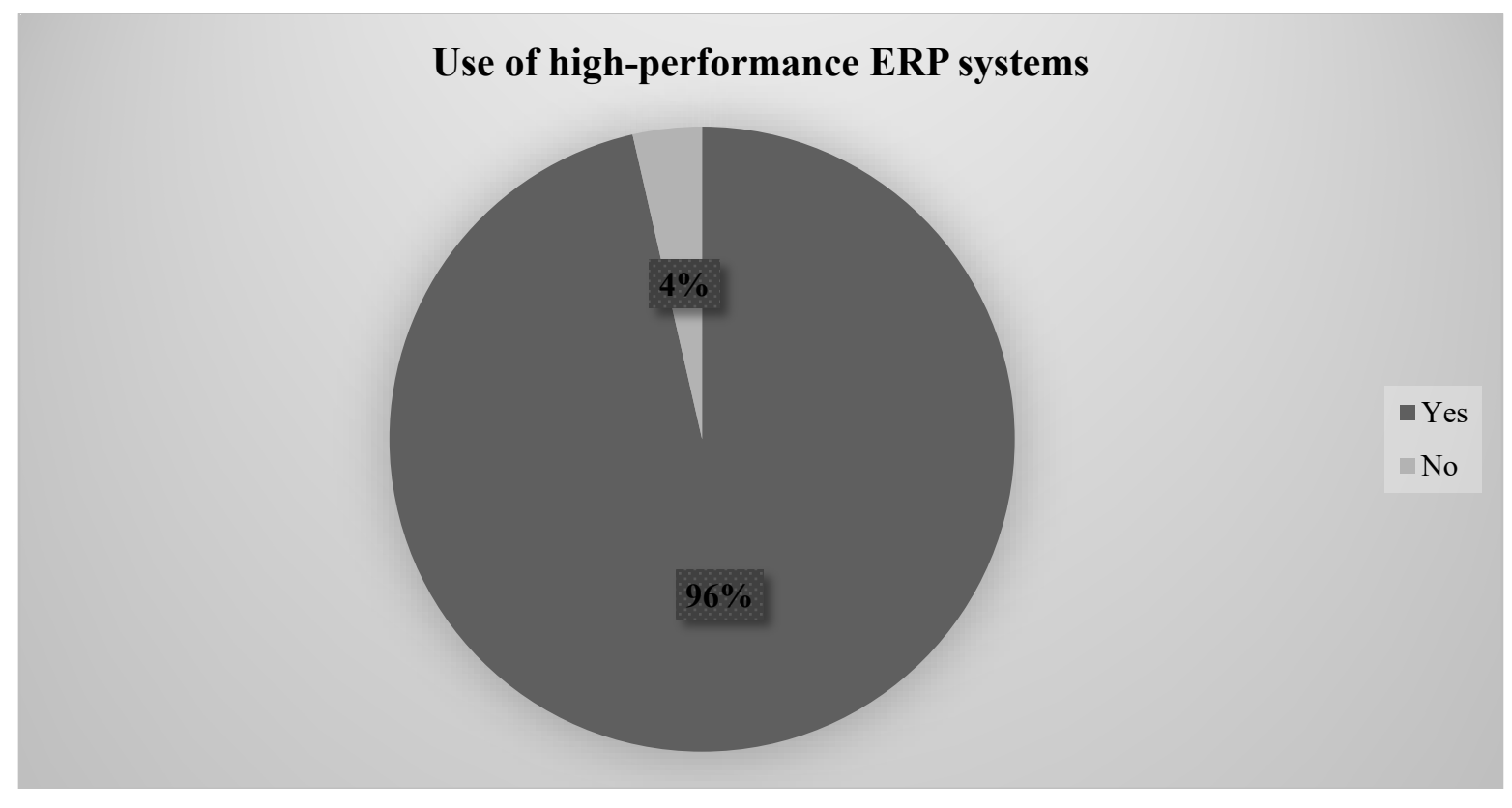

Fig. no. 4: Use of high-performance ERP systems

Source: own creation

Thus, a correct maintenance of the IT equipment and of the ERP type information systems must be ensured periodically, so as to ensure their correct function.

The systems must be flexible so that the work tasks are performed in the best possible conditions.

\section{Conclusions}

The continuous development of the business environment has determined the digitization of a very large number of activities carried out by organizations. The main reason that was the basis for digitizing the organization's activity was the desire to simplify the way information is processed within the organization.

The efficiency of ERP systems leads to increased productivity and sustainable development of the organization. Regarding the research questions, the respondents consider that ERP systems offer them the possibility to process a larger amount of documents, thus observing an improvement in labor productivity.

The research in this article concludes with a favorable conclusion given that the modernization of ERP systems maximizes the possibilities of sustainable development because all the information provided by these ERP systems is much more accurate and complete and provides a better view of the organization.

\section{References}

Alfa Software.ro (2019), Ce este un ERP?. Available at: https://www.asw.ro/ce-este-un-erp/, accessed at: March 20,2021

ANS (2020), Platforma naţională de colectare a datelor statistice pentru învăţământul superior. Available at: https://date.invatamant-superior.ro, accessed at February 24, 2021

Bradford, M., Earp, J.B., Williams, P. (2012). Sustainability: An Analysis of Organizational Reporting and Implications for ERP systems, SAIS 2012 Proceedings. 6, pp. 30-35 
Danciu, V. (2013). Întreprinderea sustenabilă. Noi provocări și strategii pentru îmbunătățirea sustenabilității corporative. Economie teoretică și aplicată, 9 (586), pp. 4-24. Available at: http://store.ectap.ro/ articole/898_ro.pdf, accessed at February 20, 2021

Gradient Consulting (2020). ERP Systems and Sustainability. Available at: https://www.gradientconsulting. co.uk/erp-systems-and-sustainability, accessed at February 28, 2021

Hasan, M. M., Nekmahmud, M., Yajuan, L., Patwary, M. A. (2019). Green business value chain: a systematic review. Sustainable Production and Consumption, 20, pp. 326-339

Kandananond, K. (2014). A Roadmap to Green Supply Chain System Through Enterprise Resource Planning (ERP) Implementation. Procedia Engineering, 69, pp. 377-382

Karagulle, A. O. (2012). Green business for sustainable development and competitiveness: an overview of Turkish logistics industry. Procedia - Social and Behavioral Sciences, 41 pp. 456-460

Knut, H. (2016). Why all businesses should embrace sustainability. Available at: https://www.imd.org/researchknowledge/articles/why-all-businesses-should-embrace-sustainability/

Mathews, J. A. (2015). Greening of Business. International Encyclopedia of the Social \& Behavioral Sciences, 2nd edition, Vol. 10, DOI: 10.1016/B978-0-08-097086-8.73131-X

Mirghafoori, S. H., Andalib, D., Keshavarz, P. (2017). Developing Green Performance Through Supply Chain Agility in Manufacturing Industry: A Case Study Approach. Corporate Social Responsibility and Environmental Management, DOI: 10.1002/csr.1411

Novosoft LLC, Enterprise Resource Planning Systems. Available at: https://www.novosoft.net/nerpa-erp.html, accessed at June 20, 2021

Rajan, C. A., Baral, R. (2015). Adoption of ERP system: An empirical study of factors influencing the usage of ERP and its impact on end user. IIMB Management Review, 27, pp. 105-117

Stefanidis, B.V. (2017), Training-ul, formarea profesionala si dezvoltarea personala in traseul catre success. Available at: https:/www.startupcafe.ro/afaceri/training-dezvoltare-personala.htm, accessed at March 24, 2021

Transart (2021), Ce este un sistem ERP? | Beneficiile şi componentele unei aplicații ERP, available at: https://www.transart.ro/ce-inseamna-erp/, accessed at January 10, 2021

Ziarul Financiar.ro (2021), Digitalizarea companiilor mici şi mijlocii: calea către rezilienţă şi reconstrucţie. Available at: https://www.zf.ro/info/digitalizarea-companiilor-mici-si-mijlocii-calea-catre-rezilienta-si19603719, accessed at June 23, 2021 